\title{
The Effect of Informative Video to Reduce Anxiety in Patients with Third Molar Surgery
}

\author{
Nita Layli Hanifah'), Eti Poncorini Pamungkasari²), Rita Benya Adriani2) \\ 1) Masters Program in Public Health, Universitas Sebelas Maret \\ 2) Department of Public Health, Faculty of Medicine, Universitas Sebelas Maret
}

\section{ABSTRACT}

Background: Dental anxiety is one type of anxiety that provides major complications for patients and dentists. Third molar extraction is one of the most common surgical procedures in the field of oral and maxillofacial surgery which is accompanied by various anxiety triggers. Anxiety due to procedures performed during dental procedures causes anxiety 60\%-80\% in patients who will undergo surgery. This study aims to estimate the effect of providing informative videos on the level of anxiety in patients undergoing third molar surgery based on a number of previous primary studies.

Subjects and method: This study is a systematic and meta-analysis study, with the following PICO Population: Patients 18-45 years old old, Intervention: Informative video about third molar surgery, Comparison: Without informative video, Outcome: Anxiety levels. The articles used in this study were obtained from several databases, including PubMed, Scopus, Hindawi, Proquest, ScienceDirect and Google Scholar. This article was collected for 1 month. The keywords to search for articles were as follows: "Video" OR "Audiovisual" AND "Dental
Anxiety" OR "Anxiety" AND "Third Molar Surgery" AND "Randomized Controlled Trial". The articles included in this study are full text articles with a Randomized Controlled Trial study design. Articles were collected using PRISMA flow diagrams. Articles were analyzed using the Review Manager 5.3 aplikasi application

Results: A total of 9 articles were reviewed in this meta-analysis. The study showed that informative videos have an effect on reducing anxiety. (Standardized Mean Difference $=$ $0.05 ; 95 \% \mathrm{CI}=-0.19$ to $0.08 ; \mathrm{p}=0.44)$. The funnel plot indicated publication bias.

Conclusion: Informative video about dental surgery reduce anxiety levels.

Keywords: Informative video, dental anxiety, third molar surgery

\section{Correspondence:}

Nita Layli Hanifah, Masters Program In Public Health, Universitas Sebelas Maret, Jl. Ir. Sutami 36A, Surakarta 57126, Central Java. Email: Nitalaylii63@gmail.com.

Cite this as:

Hanifah NL, Pamungkasari EP, Adriani RB (2021). The Associations of Clean and Healthy Behavior, Social Capital, and Nutritional Status in Children Under Five in Waingapu Health Center. J Health Promote Behav. 06(01): 80-90. https://doi.org/10.26911/thejhpb.2021.06.01.08.

cc) (i) (2) Journal of Health Promotion and Behavioris licensed under a Creative Commons

Attribution-NonCommercial-ShareAlike 4.0 International License.

\section{BACKGROUND}

Anxiety is a feeling of restlessness, uncertainty and helplessness can also be called a state of tension which is closely related to feelings of fear. Anxiety is a normal emotional response to threats or real stressors. Mild anxiety can improve learning by helping concentration and focus. Anxiety can also provide motivation.
However, uncontrolled anxiety often leads to ineffective behavior (Bard, 2021).

The World Health Organization (WHO) 2017 states that anxiety and depression are common mental disorders and have the highest prevalence rates. In 2015, it was estimated that $3.6 \%$ of the world's population had an anxiety disorder, 
which is more common in women than men, with a ratio of $4.6 \%$ and $2.6 \%$ globally.

Dental anxiety is one type of anxiety that provides major complications for patients and dentists. This fear causes patients to delay treatment, cancel visits to the dental clinic or even avoid dental treatment. Patients with high levels of anxiety are certain to experience more damage such as caries and tooth extraction compared to patients who do not experience anxiety (Saatchi, 2015).

People with poor oral health status can have a negative impact on their social life (Strom, 2019). Patients who experience dental anxiety need more time and are often dissatisfied with the treatment that has been done. Anxiety can affect the patient's relationship with the dentist and such a situation can be a source of stress that can interfere with the dental treatment process(Toet, 2010).

Third molar extraction is one of the most common surgical procedures in oral and maxillofacial surgery which is accompanied by various anxiety triggers (Choi, 2015). Third molar extraction is associated with pain, swelling, trismus, and other complications (Ghaeminia, 2016). Anxiety due to procedures performed during dental procedures is recognized as the most common phobia in patients and causes $60 \%-80 \%$ anxiety in patients who will undergo surgery(Kazancioglu, 2015).

Some studies stated that between 50 and $80 \%$ of adults in the United States have a level of anxiety about dental care, ranging from mild to severe. More than $20 \%$ of patients who experience dental anxiety do not visit the dental clinic regularly, 9 to $15 \%$ of patients who experience anxiety avoid dental treatment(White, 2017).

High levels of anxiety during dental treatment can be a constraint, not only for patients but also for oral surgeons (Yusa,
2004). Patients with high levels of anxiety may be unreliable, uncooperative and complain excessively during procedures (Thomson, 2000). Dental treatment can cause irritation, anger and frustration among the patients, this has an effect on the high level of stress on the surgeon while performing the operation, so that it can interfere with the surgeon's performance and cause the operation time to last longer (Ekanayake, 2003).

A study shows that lack of information about surgical procedures and postoperative complications are factors that trigger anxiety that occurs before surgery. It is stronger than the fear of pain during surgery (Muglali, 2008). Increasing the knowledge about surgical procedures, including factors that are considered relevant to the treatment to be performed and postoperative recovery, this is useful in managing patients' anxiety and reducing situational anxiety (Ong, 2004).

Several studies have reported that video-based research results in better patient satisfaction and increases patient's understanding of the surgical procedure to be performed compared to verbal information or a combination of verbal and brochures (Cakmak, 2018). According to a study done by Choi in 2015, he demonstrated an informative preoperative video showing that dental surgery procedures can reduce anxiety while increasing patient understanding. This video method has proven to be a low-cost counseling media option that can increase patient knowledge and satisfaction(Nathoo, 2017).

Based on the background above, it is known that watching informative videos can affect the level of anxiety in patients who will undergo third molar surgery. Therefore, the research "Meta-analysis of the effect of giving informative videos on anxiety levels in patients who will undergo 
third molar surgery" needs to be done to see the effectiveness of informative videos on anxiety levels in patients who will undergo third molar surgery.

\section{SUBJECTS AND METHOD}

\section{Study Design}

This study is a systematic and metaanalysis study. The articles used in this study were obtained from several databases, including PubMed, Scopus, Hindawi, Proquest, ScienceDirect and Google Scholar. The keywords to search for articles are as follows: "Video" OR "Audiovisual" AND "Dental Anxiety" OR "Anxiety" AND "Third Molar Surgery" AND "Randomized Controlled Trial".

\section{Inclusion Criteria}

The articles included in this study are full paper articles with a randomized controlled trial study design. The study subjects were patients aged 18-45 years old who experienced impaction. Selected articles provide intervention in the form of informative videos about third molar surgery with anxiety level outcomes.

\section{Exclusion Criteria}

The articles published in this study were articles published before 2010 and articles that do not include the SD mean score.

\section{Operational Definition}

The search for articles was carried out by considering the eligibility criteria defined using the PICO model. The population in this study was patients aged 18-45 years old who experienced impaction, the intervention was in the form of informative videos, comparison, which was not given infor- mative videos, and the outcome in the form of anxiety levels.

Informative video intervention is a learning media in the form of moving images accompanied by sound that forms a unit that is assembled into an appropriate flow, with educational messages in it to achieve learning objectives. Instrument: a questionnaire with a categorical measurement scale.

Anxiety is a feeling of restlessness, uncertainty and helplessness that can also be called a state of tension which is closely related to feelings of fear. Instrument: questionnaire with continuous measurement scale.

\section{DataAnalysis}

Data processing is carried out by Review Manager (RevMan 5.3) by calculating the mean difference to determine the combined study model and form the final result of the meta-analysis.

\section{RESULTS}

The process of searching for articles by searching through databases with journals can be seen in Figure 1. There were 803 articles identified from the database, after the process of removing duplicate articles, there were 774 articles with 22 of them fulfilling the requirements. Articles were excluded for several reasons, so that 9 articles were included in the synthesis and meta-analysis studies.

There were 9 articles obtained from 2 continents, namely Europe and Asia. 3 studies from the European continent, 6 studies from the Asian continent. 
Hanifah et al./ Informative Video to Reduce Anxiety in Patients with Third Molar Surgery

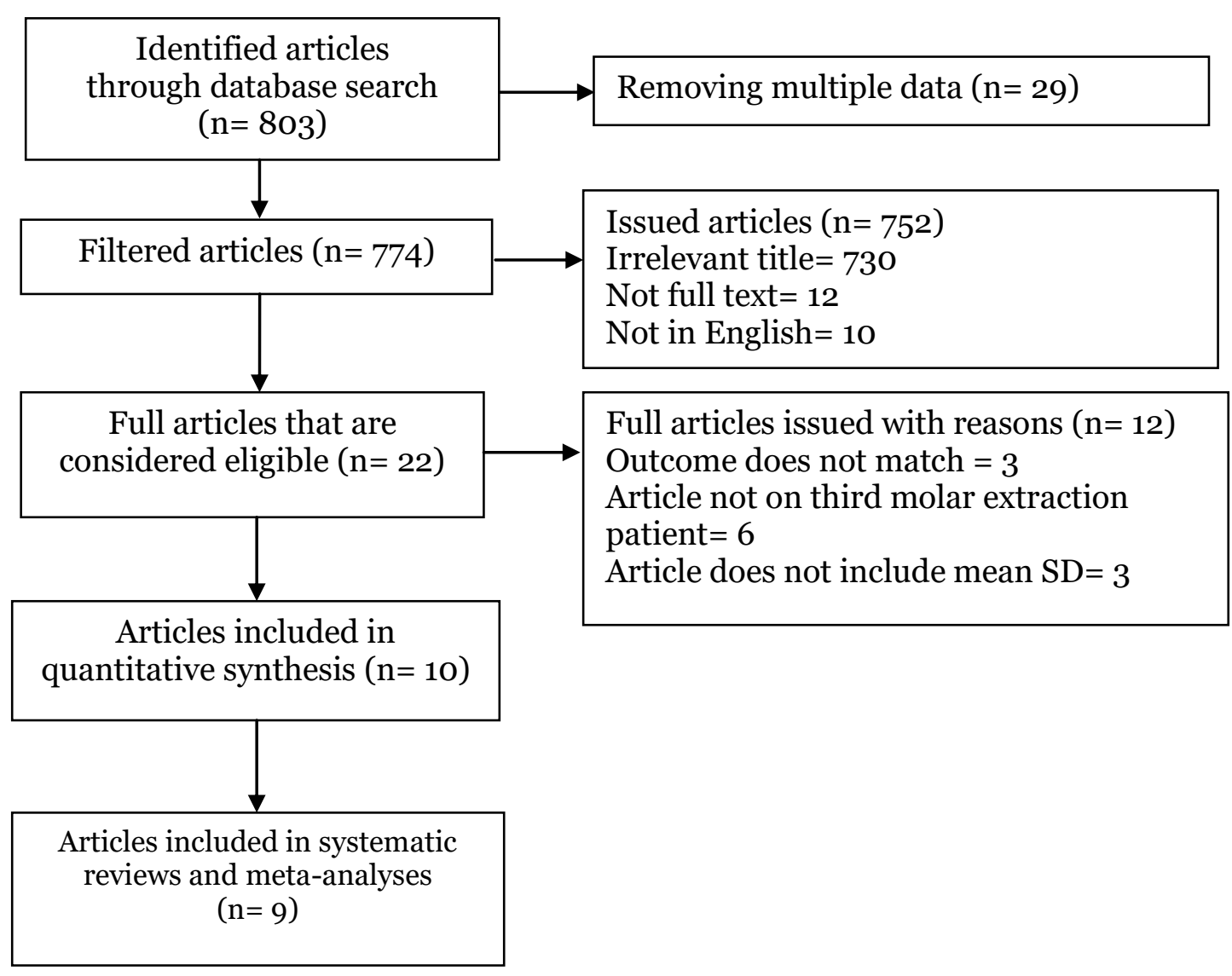

Figure 1. PRISMA Flow Diagram

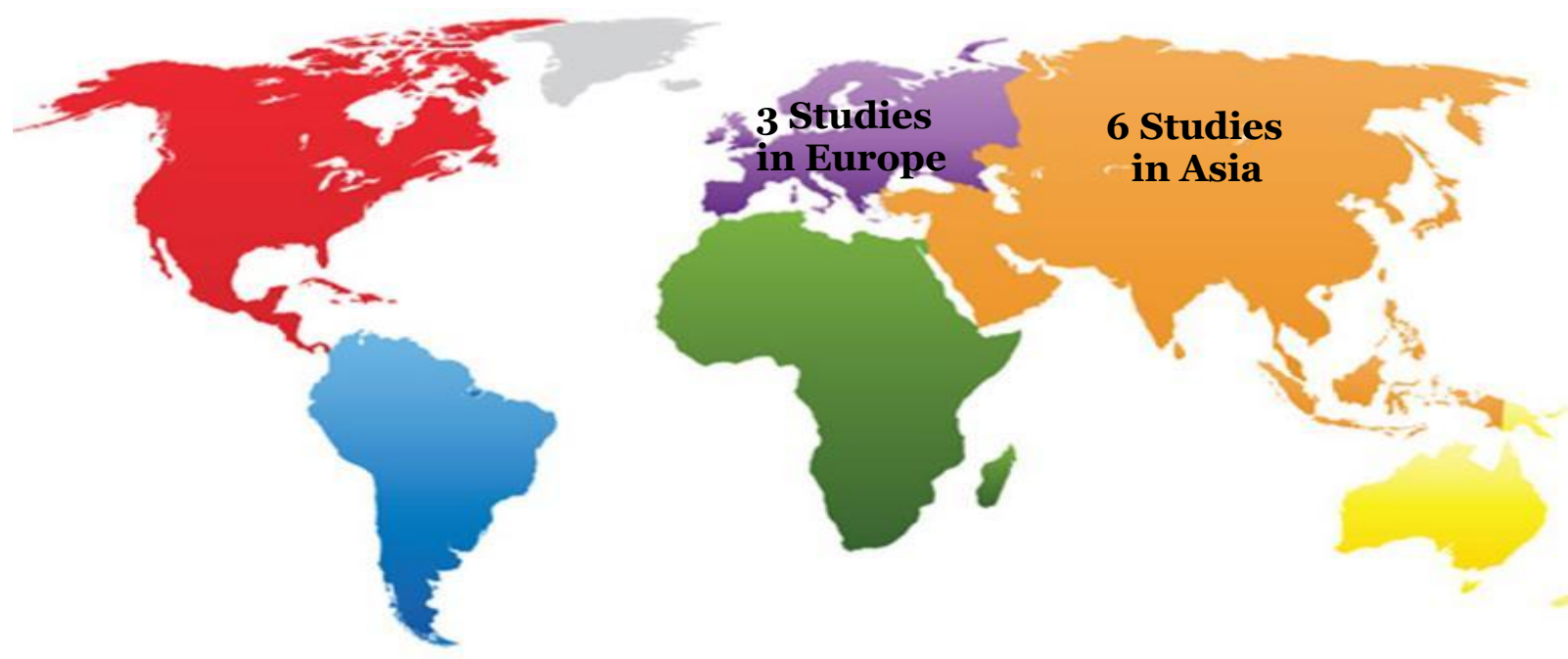

Figure 2. Map of the research area the effect of informative video on anxiety levels 
Table 1. Study quality research

\begin{tabular}{|c|c|c|c|c|c|c|c|c|c|c|}
\hline \multirow[b]{2}{*}{ No } & \multirow[b]{2}{*}{ Checklist Questions } & \multicolumn{9}{|c|}{ Publication (Author and Year) } \\
\hline & & $\begin{array}{l}\text { Serrabon } \\
\text { aet al. } \\
\text { (2020) }\end{array}$ & $\begin{array}{l}\text { Luque et al. } \\
\text { (2020) }\end{array}$ & $\begin{array}{c}\text { Lahti et } \\
\text { al.(2020) }\end{array}$ & $\begin{array}{l}\text { Kazancio } \\
\text { glu et al. } \\
\text { (2014) }\end{array}$ & $\begin{array}{l}\text { Omezli et } \\
\text { al.(2019) }\end{array}$ & $\begin{array}{l}\text { Tanidir } \\
\text { et al } \\
(\mathbf{2 0 1 6})\end{array}$ & $\begin{array}{l}\text { Choi et } \\
\text { al. }(2015)\end{array}$ & $\begin{array}{l}\text { Alfotawiet } \\
\text { al. (2020) }\end{array}$ & $\begin{array}{l}\text { Sancaket } \\
\text { al.(2019) }\end{array}$ \\
\hline 1 & $\begin{array}{l}\text { Does this study discuss a clear study } \\
\text { focus? }\end{array}$ & 1 & 1 & 1 & 1 & 1 & 1 & 1 & 1 & 1 \\
\hline 2 & $\begin{array}{l}\text { Is the Randomized Controlled Trial } \\
\text { research method suitable for } \\
\text { answering study questions? }\end{array}$ & 1 & 1 & 1 & 1 & 1 & 1 & 1 & 1 & 1 \\
\hline 3 & $\begin{array}{l}\text { Are there enough subjects in the } \\
\text { study to establish that the findings } \\
\text { did not occur by chance? }\end{array}$ & 1 & 1 & 1 & 1 & 1 & 1 & 1 & 1 & 1 \\
\hline 4 & $\begin{array}{l}\text { Were subjects randomly allocated to } \\
\text { the experimental and control groups? } \\
\text { If not, could this be biased? }\end{array}$ & 1 & 1 & 1 & 1 & 1 & 1 & 1 & 1 & 1 \\
\hline 5 & Are inclusion/exclusion criteria used? & 1 & 1 & 1 & 1 & 1 & 1 & 1 & 1 & 1 \\
\hline 6 & $\begin{array}{l}\text { Were the two groups comparable at } \\
\text { study entry? }\end{array}$ & 1 & 1 & 1 & 1 & 1 & 1 & 1 & 1 & 1 \\
\hline 7 & $\begin{array}{l}\text { Were objective and unbiased } \\
\text { outcome criteria used? }\end{array}$ & 1 & 1 & 1 & 1 & 1 & 1 & 1 & 1 & 1 \\
\hline 8 & $\begin{array}{l}\text { Are objective and validated } \\
\text { measurement methods used in } \\
\text { measuring the results? If not, were } \\
\text { results judged by someone who was } \\
\text { not aware of the group assignment (ie } \\
\text { was the assessment blinded)? }\end{array}$ & 1 & 1 & 1 & 1 & 1 & 1 & 1 & 1 & 1 \\
\hline 9 & Is effect size practically relevant? & 1 & 1 & 1 & 1 & 1 & 1 & 1 & 1 & 1 \\
\hline 10 & $\begin{array}{l}\text { How precise is the estimate of the } \\
\text { effect? Is there a confidence interval? }\end{array}$ & 1 & 1 & 1 & 1 & 1 & 1 & 1 & 1 & 1 \\
\hline 11 & $\begin{array}{l}\text { Could there be confounding factors } \\
\text { that have not been taken into } \\
\text { account? }\end{array}$ & o & o & o & o & o & o & o & o & o \\
\hline \multirow[t]{2}{*}{12} & $\begin{array}{l}\text { Are the results applicable to your } \\
\text { research? }\end{array}$ & 1 & 1 & 1 & 1 & 1 & 1 & 1 & 1 & 1 \\
\hline & Total & $\mathbf{1 1}$ & $\mathbf{1 1}$ & $\mathbf{1 1}$ & $\mathbf{1 1}$ & $\mathbf{1 1}$ & $\mathbf{1 1}$ & $\mathbf{1 1}$ & $\mathbf{1 1}$ & $\mathbf{1 1}$ \\
\hline
\end{tabular}

*In question item number 11, a score of o is given because the question has a positive score 


\section{The effect of informative videos on anxiety levels}

9 Articles prove that there is a relationship between the influence of informative videos on anxiety levels

Table 2. Description of the primary studies included in the meta-analysis primary studies

\begin{tabular}{|c|c|c|c|c|c|c|c|}
\hline $\begin{array}{l}\text { Author } \\
\text { (year) }\end{array}$ & Country & $\begin{array}{l}\text { Study } \\
\text { Design }\end{array}$ & Sample & $\begin{array}{c}\text { P } \\
\text { (Population) }\end{array}$ & $\begin{array}{c}\text { I } \\
\text { (Intervention) }\end{array}$ & $\begin{array}{c}\mathrm{C} \\
\text { (Comparison) }\end{array}$ & $\begin{array}{c}\text { O } \\
\text { (Outcome) }\end{array}$ \\
\hline $\begin{array}{l}\text { Serrabona et } \\
\text { al. (2020) }\end{array}$ & Spain & $\begin{array}{l}\text { Randomized } \\
\text { Controlled } \\
\text { Trial }\end{array}$ & $\begin{array}{l}\text { Video: } 25 \\
\text { No Video: } \\
22\end{array}$ & $\begin{array}{l}\text { Patients aged } \\
\text { 18-40 years } \\
\text { old }\end{array}$ & $\begin{array}{l}\text { Knowing the effect of watching } \\
\text { an informative video about the } \\
\text { extraction of a lower third } \\
\text { molar in an impacted patient } \\
\text { on the patient's anxiety level }\end{array}$ & $\begin{array}{l}\text { Does not provide } \\
\text { information about the effect } \\
\text { of watching informative } \\
\text { videos }\end{array}$ & $\begin{array}{l}\text { Patients' } \\
\text { anxiety level }\end{array}$ \\
\hline $\begin{array}{l}\text { Luque et al. } \\
(2020)\end{array}$ & Spain & $\begin{array}{l}\text { Randomized } \\
\text { Controlled } \\
\text { Trial }\end{array}$ & $\begin{array}{l}\text { Video: } 15 \\
\text { NoVideo: } 15\end{array}$ & $\begin{array}{l}\text { Patients aged } \\
\text { 18-40 years } \\
\text { old }\end{array}$ & $\begin{array}{l}\text { Determining the effect of } \\
\text { watching informative videos } \\
\text { with audiovisual glasses can } \\
\text { relieve anxiety }\end{array}$ & $\begin{array}{l}\text { Does not determine the } \\
\text { effect of watching } \\
\text { audiovisual glasses }\end{array}$ & $\begin{array}{l}\text { Patients' } \\
\text { anxiety level }\end{array}$ \\
\hline $\begin{array}{l}\text { Lahti et al. } \\
(2020)\end{array}$ & Finlandia & $\begin{array}{l}\text { Randomized } \\
\text { Controlled } \\
\text { Trial }\end{array}$ & $\begin{array}{l}\text { Video: } 129 \\
\text { NoVideo: } 126\end{array}$ & $\begin{array}{l}\text { Patients aged } \\
\text { 18-55 years } \\
\text { old }\end{array}$ & $\begin{array}{l}\text { Studying whether informative } \\
\text { video intervention in the form } \\
\text { of short-term virtual reality } \\
\text { can reduce anxiety before } \\
\text { dental surgery }\end{array}$ & $\begin{array}{l}\text { Does not study the effect of } \\
\text { short-term virtual reality } \\
\text { interventions }\end{array}$ & $\begin{array}{l}\text { Patients' } \\
\text { anxiety level }\end{array}$ \\
\hline $\begin{array}{l}\text { Kazancioglu } \\
\text { et al. (2014) }\end{array}$ & Turkey & $\begin{array}{l}\text { Randomized } \\
\text { Controlled } \\
\text { Trial }\end{array}$ & $\begin{array}{l}\text { Verbal: } 95 \\
\text { Video and } \\
\text { Verbal: } 102 \\
\text { No video and } \\
\text { verbal: } 103\end{array}$ & $\begin{array}{l}\text { Patients aged } \\
\text { 18-25 years } \\
\text { old }\end{array}$ & $\begin{array}{l}\text { Identify the effect of watching } \\
\text { a live video about the third } \\
\text { molar extraction process }\end{array}$ & $\begin{array}{l}\text { Does not identify the effect } \\
\text { of watching a live video } \\
\text { about the third molar tooth } \\
\text { extraction process }\end{array}$ & $\begin{array}{l}\text { Patients' } \\
\text { anxiety level }\end{array}$ \\
\hline $\begin{array}{l}\text { Omezliet al. } \\
\text { (2019) }\end{array}$ & Turkey & $\begin{array}{l}\text { Randomized } \\
\text { Controlled } \\
\text { Trial }\end{array}$ & $\begin{array}{l}\text { Video: } 56 \\
\text { No video: } 57\end{array}$ & $\begin{array}{l}\text { Patients aged } \\
18-45 \text { years } \\
\text { old }\end{array}$ & $\begin{array}{l}\text { Knowing the effect of watching } \\
\text { videos about third molar } \\
\text { surgery procedures from the } \\
\text { internet }\end{array}$ & $\begin{array}{l}\text { Does not see the effect of } \\
\text { watching videos about third } \\
\text { molar surgery }\end{array}$ & $\begin{array}{l}\text { Patients' } \\
\text { anxiety level }\end{array}$ \\
\hline $\begin{array}{l}\text { Tanidiret } \\
\text { al. (2016) }\end{array}$ & Turkey & $\begin{array}{l}\text { Randomized } \\
\text { Controlled } \\
\text { Trial }\end{array}$ & $\begin{array}{l}\text { Video and } \\
\text { sound: } 43 \\
\text { Video and } \\
\text { subtitle: } 44 \\
\text { No Video: } \\
42\end{array}$ & $\begin{array}{l}\text { Patients aged } \\
\text { 18-27 years } \\
\text { old }\end{array}$ & $\begin{array}{l}\text { Finding the ideal way to find } \\
\text { out the information needed by } \\
\text { patients by providing } \\
\text { information in the form of } \\
\text { videos about the stages of } \\
\text { wisdom tooth surgery. }\end{array}$ & $\begin{array}{l}\text { Does not provide the } \\
\text { required information in the } \\
\text { form of a video about the } \\
\text { stages of wisdom tooth } \\
\text { surgery }\end{array}$ & $\begin{array}{l}\text { Patients' } \\
\text { anxiety level }\end{array}$ \\
\hline
\end{tabular}


Hanifah et al./ Informative Video to Reduce Anxiety in Patients with Third Molar Surgery

\begin{tabular}{|c|c|c|c|c|c|c|c|}
\hline $\begin{array}{l}\text { Author } \\
\text { (year) }\end{array}$ & Country & $\begin{array}{l}\text { Study } \\
\text { Design }\end{array}$ & Sample & $\begin{array}{c}\mathbf{P} \\
\text { (Population) }\end{array}$ & $\begin{array}{c}\text { I } \\
\text { (Intervention) }\end{array}$ & $\begin{array}{c}\text { C } \\
\text { (Comparison) }\end{array}$ & $\begin{array}{c}\text { O } \\
\text { (Outcome) }\end{array}$ \\
\hline $\begin{array}{l}\text { Choi et al. } \\
\text { (2015) }\end{array}$ & Korea & $\begin{array}{l}\text { Randomized } \\
\text { Controlled } \\
\text { Trial }\end{array}$ & $\begin{array}{l}\text { No video: } 26 \\
\text { Video: } 25\end{array}$ & $\begin{array}{l}\text { Patients aged } \\
\text { 20-45 years } \\
\text { old }\end{array}$ & $\begin{array}{l}\text { Providing audiovisual } \\
\text { information containing simple } \\
\text { illustrations of third molar } \\
\text { surgery. }\end{array}$ & $\begin{array}{l}\text { No audiovisual information } \\
\text { containing simple } \\
\text { illustrations of third molar } \\
\text { surgery is provided, }\end{array}$ & $\begin{array}{l}\text { Patients' } \\
\text { anxiety level }\end{array}$ \\
\hline $\begin{array}{l}\text { Alfotawiet al. } \\
(2020)\end{array}$ & $\begin{array}{l}\text { Saudi } \\
\text { Arabia }\end{array}$ & $\begin{array}{l}\text { Randomized } \\
\text { Controlled } \\
\text { Trial }\end{array}$ & $\begin{array}{l}\text { No video: } 22 \\
\text { Video: } 18\end{array}$ & $\begin{array}{l}\text { Patients aged } \\
\text { 18-35 years } \\
\text { old }\end{array}$ & $\begin{array}{l}\text { Providing audiovisual } \\
\text { information in the form of a } \\
\text { simple cartoon animation } \\
\text { about the surgical procedure of } \\
\text { third molars. }\end{array}$ & $\begin{array}{l}\text { No audiovisual information } \\
\text { in the form of a simple } \\
\text { cartoon animation was } \\
\text { given about the surgical } \\
\text { procedure for the third } \\
\text { molar. }\end{array}$ & $\begin{array}{l}\text { Patients' } \\
\text { anxiety level }\end{array}$ \\
\hline $\begin{array}{l}\text { Sancak et al. } \\
\text { (2019) }\end{array}$ & Turkey & $\begin{array}{l}\text { Randomized } \\
\text { Controlled } \\
\text { Trial }\end{array}$ & $\begin{array}{l}\text { No video: } 22 \\
\text { Video: } 22 \\
\text { Knowing Pre- } \\
\text { vious Dental } \\
\text { Surgery Infor- } \\
\text { mation: } 22\end{array}$ & $\begin{array}{l}\text { Patients aged } \\
\text { 18-40 years } \\
\text { old }\end{array}$ & $\begin{array}{l}\text { Evaluating the effect of video } \\
\text { information on surgical } \\
\text { procedures for third molars. }\end{array}$ & $\begin{array}{l}\text { No video information is } \\
\text { provided on the } \\
\text { surgical procedure of } \\
\text { the third molar. }\end{array}$ & $\begin{array}{l}\text { Patients' } \\
\text { anxiety level }\end{array}$ \\
\hline
\end{tabular}

*Variables included in the meta-analysis 
Hanifah et al./ Informative Video to Reduce Anxiety in Patients with Third Molar Surgery

\section{Forest Plot}

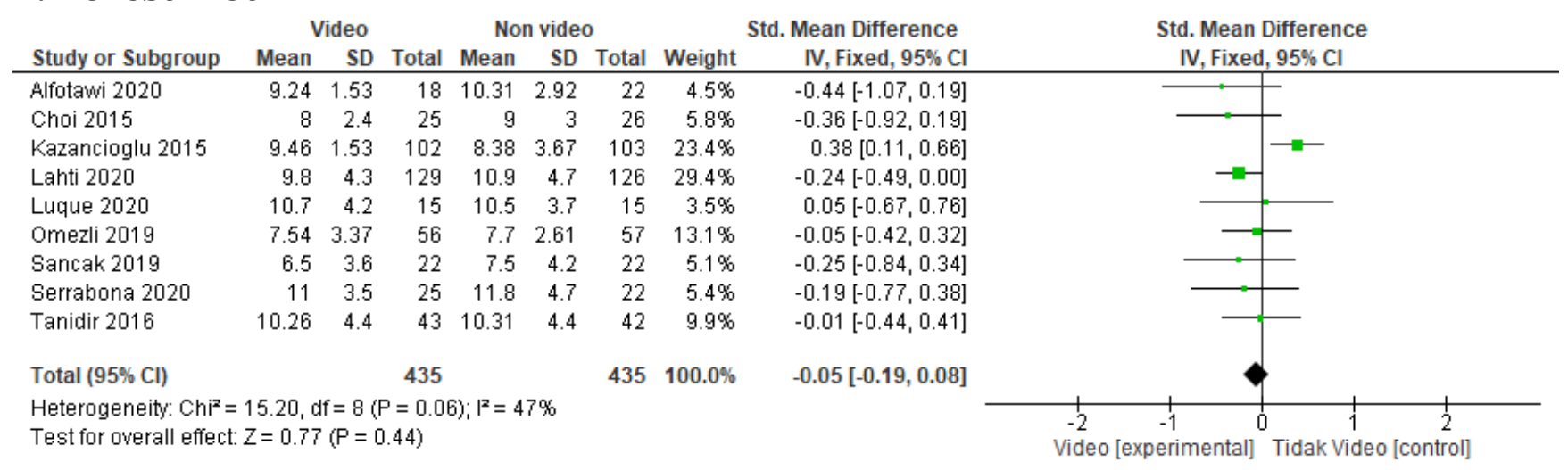

\section{Figure 3. Forest Plot of the Effect of Informative Video on Patients' Anxiety Level}

\section{Funnel Plot}

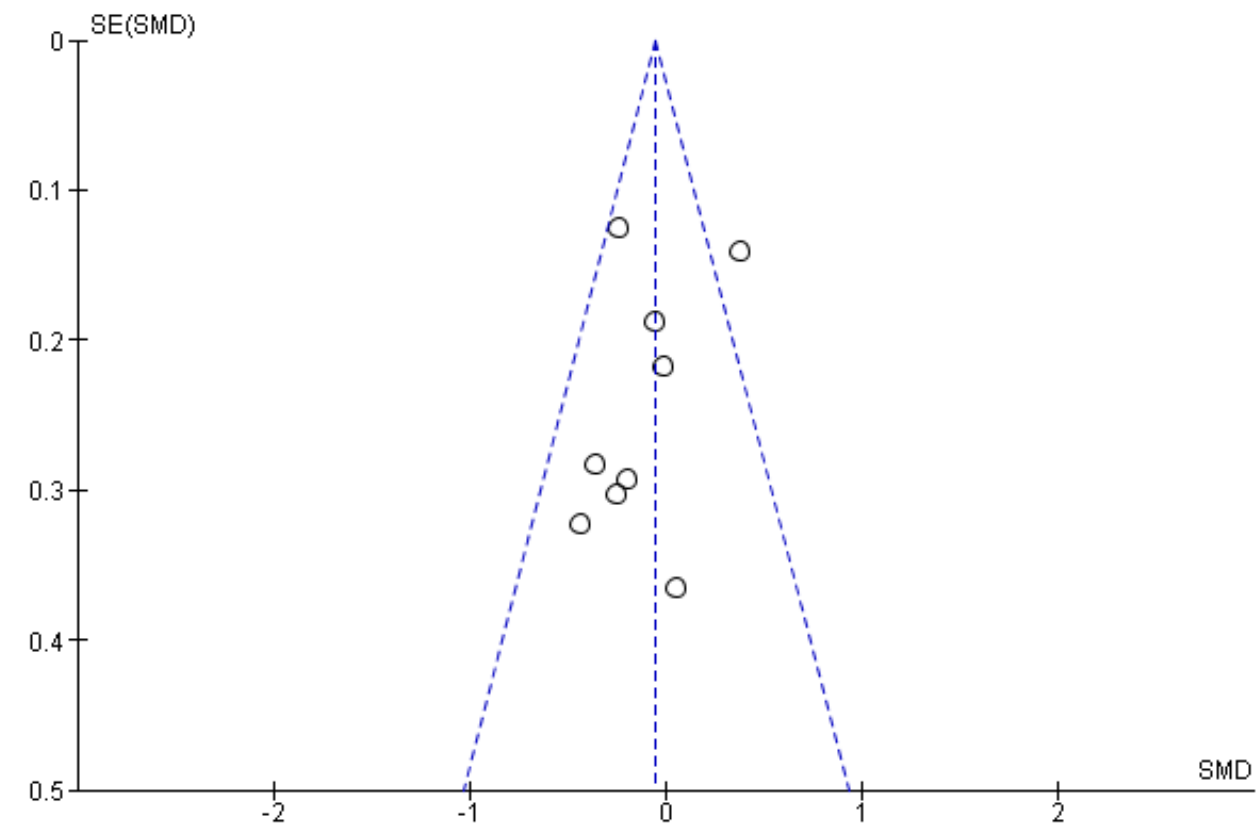

Figure 4. Funnel Plot of the Effect of Informative Video on Anxiety Levels

Based on the results of the meta-analysis process that can be seen through the forest plot (figure 3), it showed that there was a weak effect of informative video on decreasing anxiety -0.05, and not statistically significant $(\mathrm{p}=0.44)$. The heterogeneity of the study data showed I2 $=47 \%$ so that the distribution of the data was not heterogeneous (fixed effect model). Based on (figure 4), it showed that there was an asymmetric distribution of the results of the small sample primary study marked by the presence of 6 plots on the left and 3 plots on the right, this indicates a publication bias that overestimated the true effect of informative videos.

\section{DISCUSSION}

This study of systematic and meta-analysis review raised the theme of the effect of 
informative videos about third molar surgery on anxiety levels. The independent variable was informative video and the dependent variable analyzed was the level of anxiety in patients who would undergo third molar surgery. The intervention was designed to reduce the level of anxiety in patients who will undergo third molar surgery with a randomized controlled trial design. This study discussed data about the effect of informative videos which were considered important because they can increase patient knowledge about an action procedure.

This study of systematic and metaanalysis review used research that has controlled the confounding factor which can be seen from the inclusion requirements of the study, namely the Standardized mean difference. The combined estimated effect of informative video was processed by using RevMan 5.3 with the Continuous method. This method was used to analyze the effect size or standardized mean difference on bivariate data of two groups that have controlled for confounding factors by randomization. The results of the systematic study and meta-analysis were presented in the form of forest plots and funnel plots.

The results of the forest plot showed that the informative video of -0.05 reduced the level of anxiety in patients who had impacted and would have their third molars extracted compared to patients without video intervention. $(\mathrm{SMD}=-0.05 ; 95 \% \mathrm{CI}=$ -0.19 to $0.08 ; \mathrm{p}=0.44)$. The heterogeneity of the study data showed $\mathrm{I}^{2}=47 \%$ so that the distribution of the data was not heterogeneous (fixed effect model).

Serrabona et al. (2020) stated that providing preoperative information through informative videos significantly reduces the patient's level of anxiety during surgical procedures. The videos include reassuring information and instructions that make the patient feel comfortable. Therefore, the reduction of anxiety in dental care can be caused by one of these factors.

This study was in line with Choi et al. (2015) where the results showed that informing patients about a treatment procedure with audiovisual presentations can increase patient knowledge about postoperative complications and help to reduce anxiety after surgical extraction of impacted third molars.

Alfotawi et al (2020) mentioned that audio-visual presentations can minimize patient anxiety during surgical removal of impacted third molars. This is due to a better understanding of the surgical procedure and the potential complications that may occur. A balanced amount of information is usually conveyed on video in a soothing tone of voice, which is the most important factor as it has been found that overly detailed listings and disclosures prior to extraction of impacted third molars can increase patient stress.

\section{AUTHOR CONTRIBUTION}

Nita Layli Hanifah is the main researcher who selected the topic, searched and collected study data. Eti Poncorini Pamungkasari and Rita Benya Adriani played a role in analyzing data and reviewing study documents.

FUNDING AND SPONSORSHIP This study uses personal funds from the main researcher.

\section{CONFLICT OF INTEREST}

There is no conflict of interest.

\section{ACKNOWLEDGMENT}

We are very grateful to the database providers: PubMed, Scopus, Hindawi, 
Hanifah et al./ Informative Video to Reduce Anxiety in Patients with Third Molar Surgery

Proquest, ScienceDirect and Google Scholar.

\section{REFERENCES}

Alfotawi R, Alhowikan A, Alfadhel A, Premnath S, Tawhari J, Alhamid A, Bahammam S (2020). A Novel assessment tool monitoring the level of patient anxiety during third molar surgery procedure. Heliyon, 6(1). https://doi.org/10.1016/j.heliyon.2019.e02576.

Bard B, Macmullin E, Williamson J (2021). Morrison-Valfre's foundations of mental health in Canada, 1e EBook. Canada: Elsevier.

Cakmak M, Kose I, Zinzircioglu C, Karaman Y, Tekgul Z T, Pektas S, Bozkurt P. S. (2018). Effect of video-based education on anxiety and satisfaction of patients undergoing spinal anesthesia. Braz J Anesthesiol. 68(3): 274279. https://doi.org/10.1016/j.bjan.2018.01.001.

Choi SH, Won JH, Cha JY, Hwang CJ (2015). Effect of audiovisual treatment information on relieving anxiety in patients undergoing impacted mandibular third molar removal. J Oral Maxillofac Surg. 73(11):2087-92. https://doi.org/10.1016/j.joms.2015.0 6.175 .

Ekanayake L, Dharmawardena D (2003). Dental anxiety in patients seeking care at the University Dental Hospital in Sri Lanka. Community Dent Health. 20(2): 112-6.

Ghaeminia H, Perry J, Nienhuijs MEL, Toedtling V, Tummers M, Hoppenreijs TJM, Mettes TG (2016). Surgical removal versus retention for the management of asymptomatic disease-free impacted wisdom teeth. Cochrane Database Syst Rev. (8): CDoo3879. https://doi.org/10.1002/14651858.CDoo3879.pub4.
Kazancioglu HO, Tek M, Ezirganli S, Demirtas N (2015). Does watching a video on third molar surgery increase patients' anxiety level?. Oral Surg Oral Med Oral Pathol Oral Radiol. 119(3): 272-7. https://doi.org/10.1016/j.oooo.2014.10.012.

Muglali M, Komerik N (2008). Factors related to patients' anxiety before and after oral surgery. J Oral Maxillofac Surg. 66(5): 870-7. https://doi.org/10.1016/j.joms.2007.06.662.

Nathoo D (2017). Video material as an effective educational tool to address informational and educational needs of cancer patients undergoing radiation therapy. J Cancer Educ. 32(2): 219-227. https://doi.org/10.1007/s13187-015-0933-x.

Ong CKS, Seymour RA, Chen FG, Ho VCL (2004). Preoperative ketorolac has a preemptive effect for postoperative third molar surgical pain. Int J Oral Maxillofac Surg. 33(8): 771-6. https://doi.org/10.1016/j.ijom.2004.01.020

Saatchi M, Abtahi M, Mohammadi G, Mirdamadi M, Binandeh E (2015). The prevalence of dental anxiety and fear in patients referred to Isfahan Dental School, Iran. Dent Res J (Isfahan). 12(3): 248-253. https://www.ncbi.nlm.nih.gov/pubmed/2600 5465 .

Strøm K, SkaareA B, Willumsen T (2020). Dental anxiety in 18-year-old Norwegians in 1996 and 2016. Acta Odontol Scand. 78(1): 13-19. https://doi.org/10.1080/00016357.2019.1637933.

Thomson W M, Locker D, Poulton R (2000). Incidence of dental anxiety in young adults in relation to dental treatment experience. Community Dent Oral Epidemiol. 28(4): 289-94. https://doi.org/10.1034/j.1600-0528.2000.280407.x 
Toet A, Smeets MA, van Dijk E, Dijkstra D, van den Reijen L. (2010). Effects of pleasant ambient fragrances on dental fear: Comparing apples and oranges. hemosens Percept. 3(3): 182-189. https://dx.doi.org/10.1007\%2Fs1207 8-010-9078-9.

Toledano-Serrabona J, Sánchez-Torres A, Camps-Font O, Figueiredo R, GayEscoda C, Valmaseda-Castellón E (2020). Effect of an informative video on anxiety and hemodynamic parameters in patients requiring mandibular third molar extraction: A randomized clinical trial. J Oral Maxillofac Surg. 78(11): 1933-1941. https://doi.org/10.1016/j.joms.2020.06.024.
White A M, Giblin L, Boyd LD (2017). The Prevalence of Dental Anxiety in Dental Practice Settings. J Dent Hyg. 91(1): 30-34.

World Health Organization (2017). Depression and other common mental disorders: global health estimates.

Yusa H, Onizawa K, Hori M, Takeda S, Takeda H, Fukushima S, Yoshida $\mathrm{H}$ (2004). Anxiety measurements in university students undergoing third molar extraction. Oral Surg Oral Med Oral Pathol Oral Radiol Endod. 98(1): 23-7. https://doi.org/10.1016/j.triple0.2003.12.017. 